\title{
Mid-Iong Term Results of Dorsal Approach and Temporary Fixation Procedure in Overlooked Perilunate Carpal Dislocation
}

\author{
Gözden Kaçan Perilunat Karpal Dislokasyonda Dorsal Yaklaşım ve Geçici Tespit \\ Prosedürünün Orta-Uzun Dönem Sonuçları
}

\author{
(D) Mehmet Ümit ÇETIN ${ }^{1}$, (1) Abdulkadir SARI ${ }^{1}$, (1) Fırat FIDAN², (1) Abdulkadir POLAT ${ }^{3}$, (1) ismail Bülent ÖZÇELiK ${ }^{4}$ \\ ${ }^{1}$ Tekirdağ Namık Kemal University Faculty of Medicine, Department of Orthopedics and Traumatology, Tekirdağ, Turkey \\ 2VM Medical Park Maltepe Hospital, Clinic of Orthopedics and Traumatology, istanbul, Turkey \\ ${ }^{3}$ Gaziosmanpaşa Training and Research Hospital, Clinic of Orthopedics and Traumatology, Istanbul, Turkey \\ 4 istanbul Yeni Yüzyıl University Gaziosmanpaşa Hospital, Clinic of Hand and Microsurgery, istanbul, Turkey
}

\begin{abstract}
Aim: Our aim in this study is to present our mid-long term functional and radiological results after open reduction with dorsal approach, K-wire application and scapholunate ligament repair in cases with perilunate dislocation.

Materials and Methods: Eleven patients who applied for perilunate dislocation between 2014 and 2018 and were followed up for at least 18 months were included in our study. The scapholunate angle, scapholunate gap, arthrosis, and avascular necrosis were evaluated in cases with isolated perilunate dislocations. The wrist flexion-extension and pronation-supination range of motion (ROM) of the patients were measured using a goniometer, and the wrist grip strength using a Jamar dynamometer. Functionally, the cases were evaluated according to the Disabilities of the Arm, Shoulder and Hand (DASH) scoring and the Herzberg clinical scoring system.

Results: The mean age was 41.1 (28-64) years, the mean follow-up time was 3.8 (1.5-6) years. The mean scapholunate angle was $49.1 \pm 8.7$ (37.370.4) degrees, the mean scapholunate gap was $2.0 \pm 0.5(1.2-2.8) \mathrm{mm}$, the mean flexion-extension ROM was $131 \pm 17.5$ (90-155) degrees, and the mean pronation-supination ROM was $155.4 \pm 6.1(140-160)$ degrees. Patients had a mean DASH score of 5.6 $\pm 3.2(0-10.9)$ and a mean Herzberg clinical score of $89.1 \pm 9.4$ (70-100).

Conclusion: In perilunate dislocations, early and appropriate treatment is the main determinant of prognosis. Close follow-up of these injuries for at least 18 months is extremely important in terms of possible complications.
\end{abstract}

Keywords: Perilunate dislocation, carpal instability, arthrosis

ÖZ

Amaç: Çalışmadaki amacımız, perilunat çıkıklı olgularda dorsal yaklaşımla açık redüksiyon, K-teli uygulaması ve skafolunat ligaman tamiri sonrası orta-uzun dönem fonksiyonel ve radyolojik sonuçlarımızı sunmaktır.

Gereç ve Yöntem: 2014-2018 yılları arasında perilunat çıkık nedeniyle başvuran, en az 18 aylık takibi olan 11 hasta çalışmamıza dahil edildi. Bu olgularda, skafolunat açı, skafolunat gap, artroz ve avasküler nekroz varlığı değerlendirildi. Hastaların el bileği fleksiyon-ekstansiyon ve pronasyonsupinasyon hareket açıklığı gonyometre ile ölçüldü. Jamar dinamometresi ile el bileği kavrama gücü değerlendirildi. Olgular fonksiyonel olarak Kol, Omuz ve El Sorunları Anketi (DASH) skorlaması ve Herzberg klinik skorlama sistemine göre değerlendirildi.

Bulgular: Ortalama yaş 41,1 (28-64), ortalama takip süresi 3,8 (1,5-6) yıldı. Ortalama skafolunat açı 49,1 $\pm 8,7(37,3-70,4)$ derece, skafolunat interval

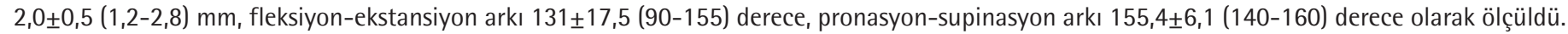

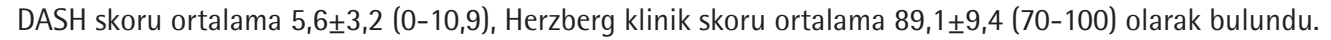

Address for Correspondence: Abdulkadir Sarı MD, Tekirdağ Namık Kemal University Faculty of Medicine, Department of Orthopedics and Traumatology, Tekirdağ, Turkey Phone: +90 5065424276 E-mail: drortopedist@yahoo.com ORCID ID: orcid.org/0000-0003-3416-5666 Received: 08.02.2021 Accepted: 28.04.2021 
Sonuç: Perilunat çıkıklarda tedavinin erken dönemde ve uygun şekilde yapılması prognozdaki ana belirleyicidir. Bu yaralanmaların olası komplikasyonlar açısından minimum 18 aylık yakın takibi son derece önemlidir.

Anahtar Kelimeler: Perilunat çııı, karpal instabilite, artroz

\section{INTRODUCTION}

Carpal stability is defined as the preservation and maintenance of the static and dynamic balance of the joints under physiological loads and movements of the wrist. On the other hand, carpal instability is defined as disruption of this balance by bone and/or ligament injuries, resulting in disruption of articular anatomical integrity, biomechanical performance impairment, pain, and scapholunate advanced collapse (SLAC) ${ }^{1}$.

Perilunate dislocations are rare, serious injuries. While approximately $65 \%$ of the cases are accompanied by scaphoid fractures, they are called major arch injuries and only ligamentous injuries are called minor arch injuries².

Among carpal injuries, dislocations are rare injuries. They constitute about $10 \%$ of carpal bone injuries. It is often caused by motor vehicle injuries and falling from height. Usually, young men are affected ${ }^{3}$. Characteristically, it presents as a dislocation of the joint between the capitate bone head and the distal lunate. Dislocation mostly develops dorsal and presents as a progressive form of bone and ligament damage 4 .

Treatment modalities including closed reduction and immobilization with plaster, closed reduction and percutaneous fixation and open reduction, ligament repair and fixation are used in the treatment ${ }^{5}$.

In the study, we aimed to present our mid-long term functional and radiological results after open reduction with dorsal approach, K-wire application and scapholunate ligament repair due to isolated perilunate injury (minor arch injury).

\section{MATERIALS AND METHODS}

Ethics committee approval was obtained for the study from Tekirdağ Namık Kemal University Faculty of Medicine Ethics Committee (29.12.2020/2020.263.12.08). The research was conducted in accordance with the principles of the Declaration of Helsinki. Twenty-two patients who presented with perilunate dislocation between 2014 and 2018 and had at least 18 months of follow-up were included in our study. Major arch injuries, chronic cases ( $>45$ days), additional wrist injuries other than radius styloid fracture that might impair wrist functions, previous trauma and operation history affecting the same extremity, cases that remained conservative, cases with neurological and rheumatological diseases were not included in the study.
Eleven patients who did not meet the criteria were excluded from the study, one of them was chronic injury and lunate avascular necrosis developed (three-year trauma), 8 patients had perilunate injury accompanied by scaphoid fracture (major arch injury), and closed reduction was performed in 2 patients. A total of 11 patients with isolated perilunate dislocation were included in the study. The mean time between trauma and surgery in our patients was 7.4 (1-32) days. Two of these patients had accompanying radius styloid fractures, and in these cases, the fracture in the distal radius was fixed with a percutaneous K-wire (Figure 1A-E).

All of our patients included in our study underwent open reduction with a dorsal approach, ligament repair and percutaneous fixation. Scapholunate ligament repair was performed using remnants of the ligament with the aid of a rope anchor placed on the lunate bone. After open reduction, one or more of the scapholunate, lunotriquetral, lunocapitate or lunoradial temporary pins were applied to our patients with $1.2 \mathrm{~mm}$ thick $\mathrm{K}$-wires, making a peroperative decision according to the condition of injury or stability (Figure 2A-D).

A splint was applied until the postoperative sutures were removed, and then a long arm cast was applied for 6-10 weeks. The controls of the cases were done with two weeks intervals in the early period after the sutures were removed. The cases were called for controls every 3 weeks between the $6^{\text {th }}$ and $12^{\text {th }}$ weeks and every 2 months in the following periods.

In cases where lunoradial K-wires were applied, they were removed at the $6^{\text {th }}$ week, while the other wires were removed at the $10^{\text {th }}$ week. Passive exercise was started on the same day, and active range of motion (ROM) exercises were started two weeks later, and axial loading was limited until the $6^{\text {th }}$ month. At the last control of our patients, two-way radiographs (anteroposterior and lateral) were taken and the scapholunate angle and scapholunate gap, the presence of arthrosis in the joint, the presence of SLAC and avascular necrosis were evaluated (Figure 3A-F). Wrist flexion-extension arc and pronation-supination arc of the patients were measured with a goniometer. The cases were evaluated according to the wrist grip strength with a Jamar dynamometer, Disabilities of the Arm, Shoulder and Hand (DASH) scoring and the clinical scoring system defined by Herzberg for perilunate injuries ${ }^{4}$. 


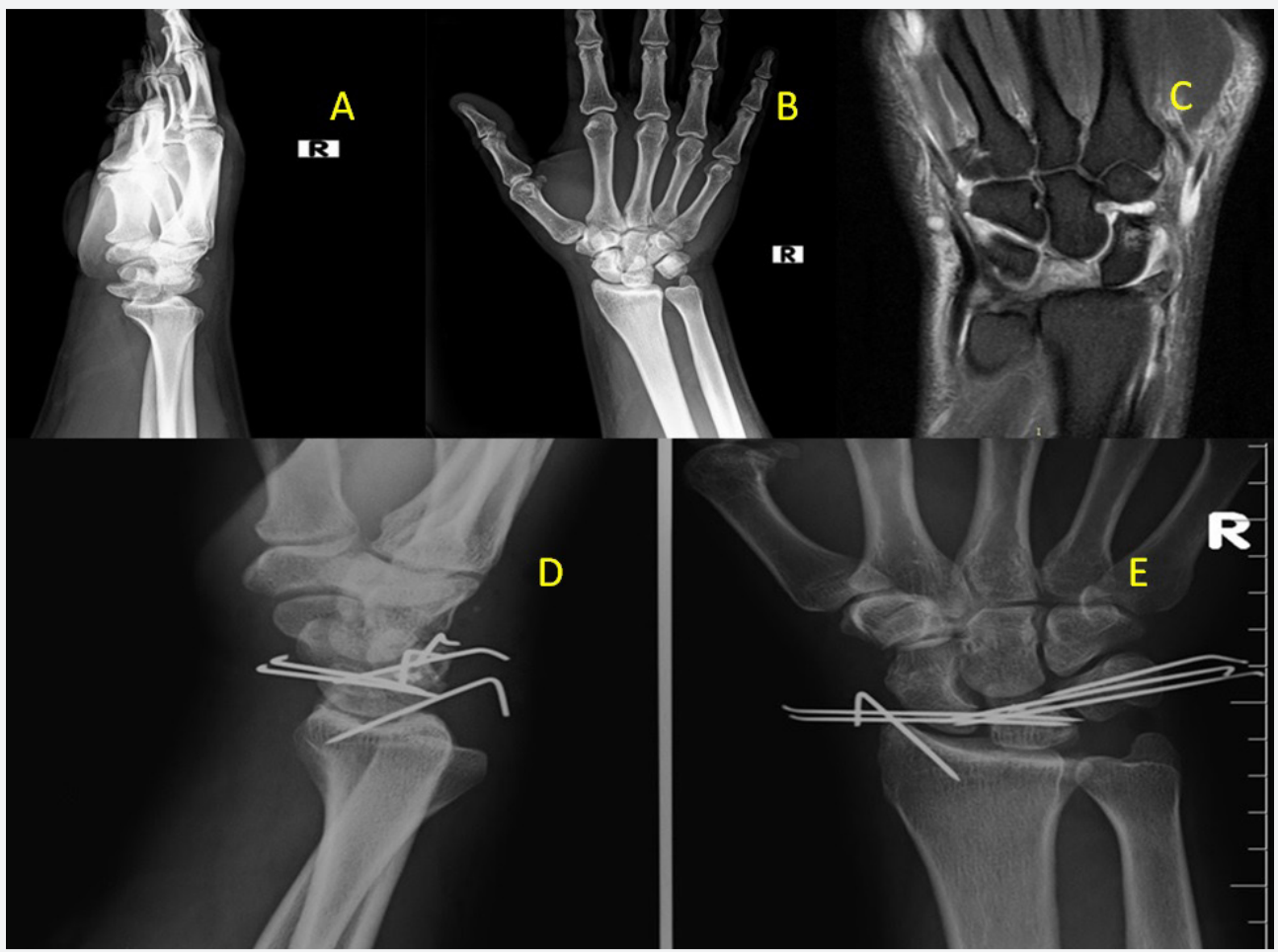

Figure 1. Preoperative and postoperative radiographs of the case with a styloid fracture of the radius. A) Perilunate dislocation and radial styloid process fracture lateral image, B) Anteroposterior image, C) Magnetic resonance image, D) Postoperative lateral image, E) Postoperative anteroposterior image

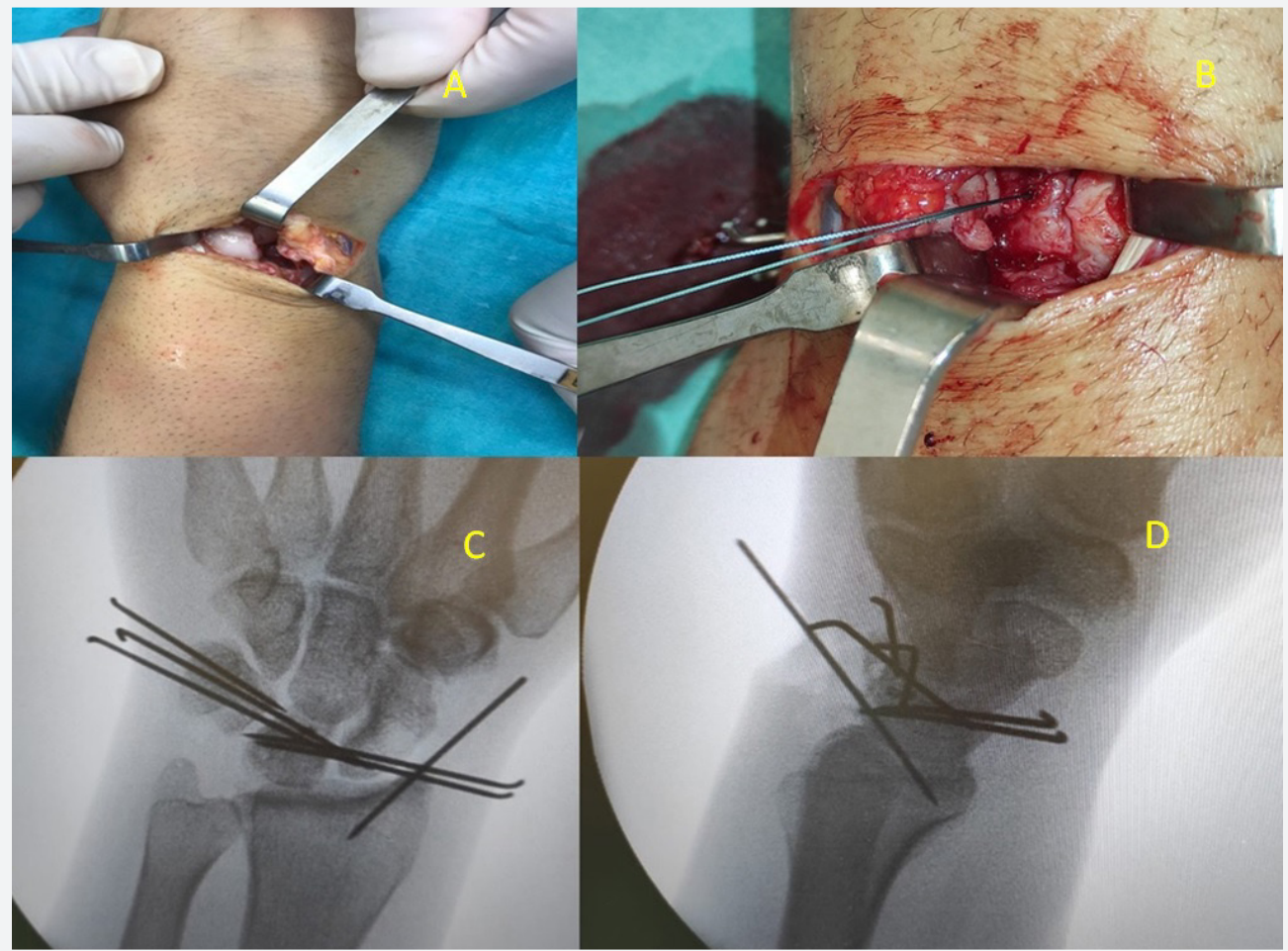

Figure 2. Peroperative evaluation of isolated perilunate dislocation and scapholunate ligament repair. A) Imaging of dorsal incision and perilunate dislocation, B) Repair of scapholunate ligament, C) Peroperative anteroposterior scopy image, D) Peroperative lateral scopy image 


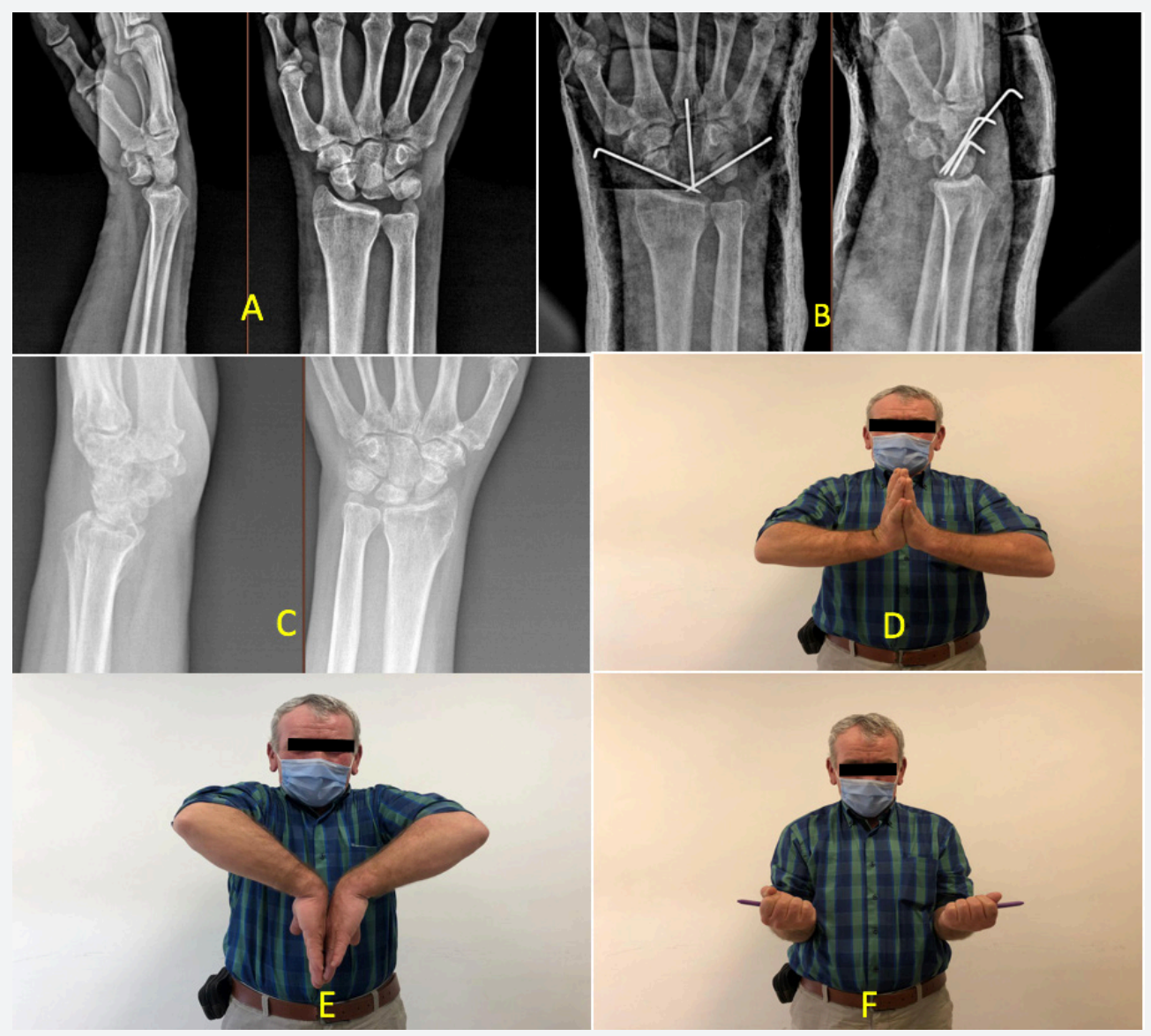

Figure 3. X-rays and functional results of the isolated perilunate dislocation case. A) Perilunate dislocation preoperative $X$-ray images, B) Fixation with scapholunate, lunotriquetral and capitolunate K-wires, C) Postoperative $3^{\text {rd }}$ year X-ray images, D) Follow-up wrist joint dorsiflexion of the case, E) Follow-up wrist joint volar flexion of the case, F) Follow-up wrist joint rotation of the case

\section{Statistical Analysis}

Variables were given as percentage, mean (arithmetic mean) and standard deviation (minimum-maximum), and nonparametric tests were used for evaluation because the number of patients was relatively small and there was no comparison group.

\section{RESULTS}

All of our patients included in the study were male and the mean age was 41.1 (28-64) years. The mean follow-up period was $3.8(1.5-6)$ years. The dominant side was affected in 7 (64\%) of our patients. High-energy trauma was often present in the etiology (Table 1). SLAC or avascular necrosis was not observed in any of our cases. Wrist arthrosis findings were observed in only one case. In this case, the flexion-extension arc was relatively low, but there was no complaint of discomforting pain. The mean time between trauma and surgery in our patients was 7.4 (1-32) days.
The mean scapholunate angle was measured as $49.1 \pm 8.7$ (37.370.4) degrees, we had only 1 patient above the normal range $\left(30^{\circ}-60^{\circ}\right)$. The scapholunate interval was $2.0 \pm 0.5(1.2-2.8) \mathrm{mm}$, and all of our patients were within normal interval $(<3 \mathrm{~mm})$ (Table 2).

The mean flexion-extension arc was $131 \pm 17.5$ (90-155) degrees, and the mean pronation-supination arc was $155.4 \pm 6.1$ (140-160) degrees (Table 2).

The mean DASH score was $5.6 \pm 3.2(0-10.9)$, and the mean clinical score described by Herzberg was 89.1 \pm 9.4 (70-100). Excellent results were found in 5 patients, good results in 5 patients, and normal results in one patient (Table 2).

We observed that the ratio of the grip strength of the operated and healthy sides in our patients, whom we evaluated in terms of wrist grip strength, was between $65 \%$ and $100 \%$.

Although none of our patients showed signs in favor of carpal tunnel syndrome at the last follow-up, in one of our 
Table 1. Evaluation according to the etiology of injury

\begin{tabular}{|l|l|l|l|l|}
\hline Occurrence mechanism & Number of cases & Percentage & Valid percentage & Cumulative percentage \\
\hline Traffic accident & 6 & 54.5 & 54.5 & 54.5 \\
\hline Falling from the height & 4 & 36.4 & 36.4 & 90.9 \\
\hline Sports injury & 1 & 9.1 & 9.1 & 100.0 \\
\hline Total & 11 & 100.0 & 100.0 & \\
\hline
\end{tabular}

Table 2. Descriptive statistical analysis of the cases

\begin{tabular}{|l|l|l|l|l|l|}
\hline & N & Minimum & Maximum & Mean & Standard deviation \\
\hline Age (year) & 11 & 28.0 & 64.0 & 41.182 & 12.1476 \\
\hline Time for surgery (days) & 11 & 1.00 & 32.00 & 7.3636 & 10.36603 \\
\hline Scapholunate angle (degrees) & 11 & 37.30 & 70.40 & 49.1182 & 8.75326 \\
\hline Scapholunate gap (mm) & 11 & 1.20 & 2.80 & 2.0545 & 0.53733 \\
\hline Flexion-extension arc (degrees) & 11 & 90.00 & 15.00 & 130.9091 & 17.58098 \\
\hline Pronation-supination arc (degrees) & 11 & 140.00 & 160.00 & 155.4545 & 6.10514 \\
\hline DASH & 11 & 0.00 & 10.90 & 5.5909 & 3.25068 \\
\hline Herzberg score & 11 & 70.00 & 100.00 & 89.0909 & 9.43880 \\
\hline Jamar operated (kg) & 11 & 15.00 & 35.00 & 27.2727 & 6.31016 \\
\hline Jamar intact $(\mathrm{kg})$ & 11 & 16.00 & 46.00 & 29.9091 & 9.81279 \\
\hline DASH: Disabilities of the Arm, Shoulder and Hand & & & & \\
\hline
\end{tabular}

patients who presented late, findings in favor of carpal tunnel syndrome were detected in the preoperative evaluation. However, no additional intervention was needed in this case, and the symptoms of the case, which was followed closely, disappeared completely in the $6^{\text {th }}$ month.

\section{DISCUSSION}

Carpal injuries are rare injuries, which complicates the classification and treatment of these injuries. The main factor affecting the outcome is the delay of treatment ${ }^{6}$. Herzberg divided these injuries into three according to the timing of treatment: Those treated in the first week; acute phase, delayed phase between eight and forty-five days; and chronic phase after 45 days $^{4}$. The most common reason for delay in treatment is failure to diagnose in the early period. This condition is encountered in approximately $25 \%$ of cases ${ }^{6}$. In our practice, we have observed that the time between trauma and surgery can differ up to 3 years in these patients. Surgery was performed in the acute phase in 6 of our cases and in the delayed phase in the remaining 5 cases. Although the relatively small number of our patients did not provide clear statistical data, we observed a close relationship between functional scores and time of surgery. The functional results of our patients who underwent surgery in the acute phase were found to be better, but it is not possible to present a healthy result because other variables (scapholunate angle, gap, and presence of arthrosis) must be evaluated for this.
Although the palmar ligaments in the scaphoid proximal pole are theoretically important stabilizers, it is difficult to repair them by direct observation ${ }^{7}$. There are also publications showing that possible carpal tunnel syndrome can be treated in the same session by using the volar approach ${ }^{8}$. The reason why we prefer the dorsal approach in our practice is to have the chance to directly observe the scapholunate interval in addition to reduction with the dorsal approach and subsequent pin placement with direct observation.

In addition, the ability to easily repair the dorsal scapholunate ligament can be considered as another advantage of this approach. There was no difficulty in finding the ligament to be repaired in any of our cases, which might be related to the fact that our patients were not in the chronic period.

It is a known fact that persistence of the scapholunate gap above $3 \mathrm{~mm}$ adversely affects the results and causes instability ${ }^{7}$. In our study, we did not observe a gap exceeding $3 \mathrm{~mm}$ in any of our patients, and we did not observe any findings in favor of instability in any of our patients.

It has been reported in the literature that a scapholunate angle greater than $70^{\circ}$ will lead to poor results ${ }^{9}$. In one case (9\%), the scapholunate angle was above $60^{\circ}$. Although it did not present a healthy statistical datum due to the relatively small number of cases, the lower functional scores in this case than our other patients were considered in line with the literature. 
Wrist grip strength was found to be at the rate of $65 \%$ compared to the healthy side. Although we think that this difference is due to the fact that the dominant side of the patients is affected and the difference between trauma and surgery time is effective, more patient numbers are needed to give healthy results. In a more comprehensive study, it was reported that the results of grip strength were approximately $65 \%$ compared to the intact extremity, and the factors that adversely affected the results were reported as affected dominant extremity, major arc injuries and isolated pinning ${ }^{10}$. We think that the reason why our results are relatively better is that our patients had isolated minor arch injuries and ligament repair.

While pain, stiffness and loss of strength are other known complications, it has been reported that wrist arthrosis develops at rates of up to $58 \%$ in 8 -year follow-up 9 . In our study, we observed findings in favor of arthrosis only in 1 patient (9\%).

Proper joint restoration is an important step in treatment because carpal malalignment has been recognized as a precursor of joint arthrosis. Even with excellent bone alignment and complete ligament healing, patients should not expect to have a normal wrist. The goal of proper treatment is a stable wrist with minimal pain and a functional ROM ${ }^{11}$. All these show that perilunate dislocations are injuries that are difficult to treat and prone to complications, no matter how meticulously every step in the treatment is performed. In the light of all this information, it should be kept in mind that perilunate injuries can leave a functionally limited extremity even if the treatment is very well done, and it should also be kept in mind that the damaged structures can be treated with maximum care and close follow-up.

\section{Study Limitations}

Our study includes some limitations. These are the retrospective evaluation of the cases, the relatively small number of patients, and the absence of a comparison group. Longer follow-up data are needed for late-stage arthrosis.

\section{CONCLUSION}

In conclusion, perilunate dislocations are rare cases, and both early diagnosis and surgery have extremely important effects on functional outcomes. Long-term close follow-up of these cases is needed in terms of possible complications.

\section{Ethics}

Ethics Committee Approval: Ethics committee approval was obtained for the study from Tekirdağ Namık Kemal
University Faculty of Medicine Ethics Committee (29.12.2020/2020.263.12.08).

Informed Consent: Retrospective study.

Peer-reviewed: Externally peer-reviewed.

\section{Authorship Contributions}

Surgical and Medical Practices: M.Ü.Ç., A.S., F.F., A.P., I.B.Ö., Concept: M.Ü.Ç., F.F., Design: M.Ü.Ç., F.F., Data Collection or Processing: M.Ü.Ç., A.S., F.F., A.P., I.B.Ö., Analysis or Interpretation: M.Ü.Ç., A.P., I.B.Ö., Literature Search: M.Ü.Ç., A.S., Writing: M.Ü.Ç., A.S., I.B.Ö.

Conflict of Interest: No conflict of interest was declared by the authors.

Financial Disclosure: The authors declared that this study received no financial support.

\section{References}

1. Sugawara LM, Yanaguizawa $M$, Ikawa $M H$, Takahashi RD, Natour J, Fernandes ADRC. Instabilidade do Carpo [Carpal instability]. Rev Bras Reumatol. 2008;48:34-8.

2. Budoff JE. Treatment of acute lunate and perilunate dislocations. J Hand Surg Am. 2008;33:1424-32.

3. Linscheid RL, Dobyns JH, Beabout JW, Bryan RS. Traumatic instability of the wrist. Diagnosis, classification, and pathomechanics. J Bone Joint Surg Am. 1972;54:1612-32.

4. Herzberg G, Comtet JJ, Linscheid RL, Amadio PC, Cooney WP, Stalder J. Perilunate dislocations and fracture-dislocations: a multicenter study. J Hand Surg Am. 1993;18:768-79.

5. Elouakili I, Ouchrif Y, Najib A, Ouakrim Y, Lamrani O, Kharmaz M, et al. Une forme exceptionnelle de la luxation perilunaire du carpe [An exceptional form of perilunar carpal dislocation]. Pan Afr Med J. 2014;18:108.

6. Gellman H, Schwartz SD, Botte MJ, Feiwell L. Late treatment of a dorsal transscaphoid, transtriquetral perilunate wrist dislocation with avascular changes of the lunate. Clin Orthop Relat Res. 1988;(237):196-203.

7. Inoue G, Kuwahata Y. Management of acute perilunate dislocations without fracture of the scaphoid. J Hand Surg Br. 1997;22:647-52.

8. Başar H, Başar B, Erol B, Tetik C. Isolated volar surgical approach for the treatment of perilunate and lunate dislocations. Indian J Orthop. 2014;48:301-5.

9. Israel $D$, Delclaux $S$, André $A$, Apredoaei $C$, Rongières $M$, Bonnevialle $P$, et al. Peri-lunate dislocation and fracture-dislocation of the wrist: Retrospective evaluation of 65 cases. Orthop Traumatol Surg Res. 2016;102:351-5.

10. Dunn JC, Koehler LR, Kusnezov NA, Polfer E, Orr JD, Pirela-Cruz MA, et al. Perilunate Dislocations and Perilunate Fracture Dislocations in the U.S. Military. J Wrist Surg. 2018;7:57-65.

11. Muppavarapu RC, Capo JT. Perilunate Dislocations and Fracture Dislocations. Hand Clin. 2015;31:399-408. 